\title{
Note
}

\section{Germination Inhibitory Activity of Grandinol Analogues}

\author{
Koichi Yoneyama, Makoto KonnaI, \\ Tetsuo TaKematsu, Shigeo Yoshida,* \\ Nobutaka TAKAHASHI* \\ and Wilfrid D. CROW**
}

\section{Weed Control Research Institute, Faculty of Agriculture, Utsunomiya University, 350 Mine-machi, Utsunomiya 321, Japan \\ *Institute of Physical and Chemical Research, 2-1 Hirosawa, Wako, Saitama 351-01, Japan **Department of Forestry, The Australian National University, P.O. Box 4, Canberra, ACT 2601, Australia}

Received April 13, 1987

Through studies on the structure/activity relationships of grandinol, a germination inhibitor in Eucalyptus, ${ }^{1)}$ Bolte et al. showed that a combination of two carbonyl functionalities on a phloroglucinol nucleus was necessary for inhibition, and that the ketonic side chain must be less than four carbon units in length. ${ }^{2)}$ As their work mainly focused on the formyl/ketone and diketone types of compounds, we synthesized grandinol analogues in which the formyl group was replaced with an amide or thioamide group (I), and examined their activities on cress seed germination. We selected phloropropiophenone as the starting material because of its easy availability, and also because its ketonic side chain fitted the above-mentioned prerequisite for activity.

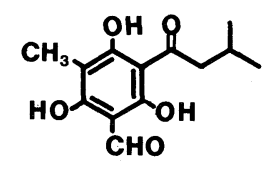

grandinol

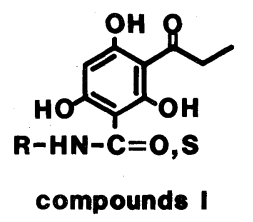

Compounds I were synthesized by direct (thio)amidation of the phlorophenone. ${ }^{3 \sim 6)}$ The $N$-methylbenzamide derivative (1) was prepared as follows; In a $100 \mathrm{ml}$ flask, $1.77 \mathrm{~g}(13.3 \mathrm{mmol})$ of anhydrous aluminum chloride was mixed with a solution of $1.32 \mathrm{~g}(10 \mathrm{mmol})$ of phloropropiophenone in dry nitrobenzene $(50 \mathrm{ml})$, and the mixture was stirred for 30 minutes at room temperature. To the clear yellowish solution was added $0.86 \mathrm{~g}(15 \mathrm{mmol})$ of methyl isocyanate, and the mixture was stirred for 24 hours at room temperature. The subsequent work-up and purification by silica gel chromatography afforded pure 1 in a $58 \%$ yield, $\operatorname{mp~} 221 \sim 222^{\circ} \mathrm{C}$. IR $v_{\max }(\mathrm{KBr}) \mathrm{cm}^{-1}: 3380$, $1640,1580,1410$. NMR $\delta_{\mathrm{H}}$ (acetone- $\left.d_{6}\right): 1.13(3 \mathrm{H}, \mathrm{t}$, $J=7 \mathrm{~Hz}), 1.90(3 \mathrm{H}, \mathrm{d}), 3.11(2 \mathrm{H}, \mathrm{q}), 5.86(1 \mathrm{H}, \mathrm{s})$. Anal. Found: C, 54.87; $\mathrm{H}, 5.64 ; \mathrm{N}, 6.24$. Calcd. for $\mathrm{C}_{11} \mathrm{H}_{13} \mathrm{NO}_{5}$ : $\mathrm{C}, 55.22 ; \mathrm{H}, 5.47 ; \mathrm{N}, 5.85 \%$. In a similar manner, compounds $2 \sim 15$ were prepared, satisfactory analytical data being obtained for all the compounds. Reactions of phloropropiophenone with other isocyanates and, in particular, with isothiocyanates required higher reaction temperatures (at $60 \sim 80^{\circ} \mathrm{C}$ for $2 \sim 3 \mathrm{hr}$ ). These reactions afforded compounds $\mathbf{I}$ as the main products. In some cases, however, migration of the acyl group in the starting material occurred during the reactions, resulting in the formation of diketones and diamides as byproducts; for example, compound $\mathbf{1 6}$ was thus obtained.

The inhibitory activities of the compounds on cress seed germination were determined as reported previously, ${ }^{2)}$ and their activities listed in Table $I$ as the $\mathrm{GI}_{50}$ values refer to the concentration of the compound $\left(10^{-5} \mathrm{M}\right)$ for which the germination rate was $50 \%$ that of untreated plots. Table I shows that not only the amide type but also the thioamide type with short $\mathrm{N}$-alkyl chains had strong activity, the most active one being 12, which was as active as grandinol. Both with the amide $(\mathbf{1} \sim \mathbf{1 0})$ and the thioamide types

TABle I. Germination Inhibitory ACtivity of Grandinol ANAlogues

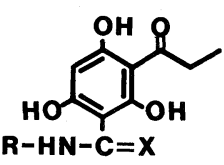

\begin{tabular}{rrccc}
\hline Compound $\mathrm{X}$ & $\mathrm{R}$ & $\mathrm{mp}\left({ }^{\circ} \mathrm{C}\right)^{*}$ & $\begin{array}{c}\mathrm{GI}_{50} \\
\left(\times 10^{-5} \mathrm{M}\right)\end{array}$ \\
\hline $\mathbf{1}$ & $\mathrm{O}$ & Methyl & $221 \sim 222$ & 40 \\
$\mathbf{2}$ & $\mathrm{O}$ & Ethyl & $210 \sim 211$ & 41 \\
$\mathbf{3}$ & $\mathrm{O}$ & Isopropyl & 203 & 39 \\
$\mathbf{4}$ & $\mathrm{O}$ & Butyl & $185 \sim 186$ & $>200$ \\
$\mathbf{5}$ & $\mathrm{O}$ & Hexyl & $140 \sim 141$ & $>200$ \\
$\mathbf{6}$ & $\mathrm{O}$ & Phenyl & dec. $210 \sim 212$ & 138 \\
$\mathbf{7}$ & $\mathrm{O}$ & 3-Me-Phenyl & dec. $181 \sim 182$ & 120 \\
$\mathbf{8}$ & $\mathrm{O}$ & 4-Me-Phenyl & dec. $229 \sim 230$ & $>200$ \\
$\mathbf{9}$ & $\mathrm{O}$ & 2-Cl-Phenyl & dec. $229 \sim 231$ & $>200$ \\
$\mathbf{1 0}$ & $\mathrm{O}$ & 4-Cl-Phenyl & dec. $219 \sim 221$ & $>200$ \\
$\mathbf{1 1}$ & $\mathrm{S}$ & Methyl & $192 \sim 194$ & 25 \\
$\mathbf{1 2}$ & $\mathrm{S}$ & Ethyl & $170 \sim 172$ & 7.7 \\
$\mathbf{1 3}$ & $\mathrm{S}$ & Propyl & $144 \sim 145$ & 35 \\
$\mathbf{1 4}$ & $\mathrm{S}$ & Butyl & $132 \sim 133$ & $>200$ \\
$\mathbf{1 5}$ & $\mathrm{S}$ & Hexyl & $114 \sim 115$ & $>200$ \\
$\mathbf{1 6}$ & \multicolumn{5}{c}{ Diamide } & dec. $226 \sim 229$ & 82 \\
\multicolumn{7}{c}{ (N, $N^{\prime}$-diisopropyl $)$} & 9.8 \\
\hline
\end{tabular}

* All melting points (mp) were not corrected. 
$(11 \sim 15)$, the inhibitory activity decreased dramatically when the number of carbon atoms in the $N$-alkyl chain exceeded three. In the case of the diketone type of analogues, similar effects from the length of the ketonic side chain on the activity were observed; the number of carbon atoms in the second ketonic side chain should be less than four for activity. These results indicate that the presumptive site of action requires strict steric limitation of the size of the substituent as proposed by Bolte et $a .^{2)}$ The diamide type (16) showed only weak activity, indicating that at least one of the acyl groups in the structure should be a ketone or another group which has stronger electron-withdrawing power than the amide group. Since the thioamide analogues $(11 \sim 13)$ were more active than the corresponding amide analogues $(\mathbf{1} \sim \mathbf{3})$, a greater difference in the electron-withdrawing potency between the two substituents in the structure may be preferable for optimum activity.

\section{REFERENCES}

1) W. D. Crow, T. Osawa, D. M. paton and R. R. Willing, Tetrahedron Lett., 1977, 1073.

2) M. L. Bolte, W. D. Crow, N. Takahashi, A. Sakurai, M. Uji-ie and S. Yoshida, Agric. Biol. Chem., 49, 761 (1985).

3) R. Leuckart and M. Schmidt, Ber., 18, 2338 (1885).

4) F. Effenberger and R. Gleiter, Chem. Ber., 92, 472 (1964).

5) P. A. S. Smith and R. O. Kan, J. Org. Chem., 29, 2261 (1964).

6) F. Effenberger, R. Gleiter, L. Heider and R. Niss, Chem. Ber., 101, 502 (1968). 